\title{
Prosesi Adat Merarik Masyarakat Bangsawan dengan Masyarakat Biasa di Desa Sengkerang Kecamatan Praya Timur Kabupaten Lombok Tengah
}

\author{
Sri Rejeki', Hermawati²
}

\begin{abstract}
${ }^{1}$ Pendidikan Pancasila dan Kewarganegaraan, Universitas Muhammadiyah Mataram, Email: umi.cici.66@gmail.com
${ }^{2}$ Pendidikan Pancasila dan Kewarganegaraan, Universitas Muhammadiyah Mataram, Email: erma97167@gmail.com
\end{abstract}

INFO ARTIKEL
Riwayat Artikel:
Diterima: 14 September
2020
Disetujui: 30 September
2020

Kata Kunci:

Adat Merarik

Masyarakat Bangsawan

Masyarakat Biasa

\begin{abstract}
ABSTRAK
Abstrak: Dalam adat istiadat masyarakat sasak terutama keturunan bangsawan khsususnya kaum perempuan, apabila ingin menikah dia harus mencari orang yang sebangsawannya, jika tidak maka harta warisan akan hangus, dan diberikan sanksi keluar dari golongan bangsawan. Sedangkan kalau laki-laki diperbolehkan menikah dengan masyarakat biasa ataupun masyarakat bangsawan. Tujuan dalam artikel ini menjelaskan prosesi adat merarik masyarakat bangsawan dengan masyarakat biasa di Desa Sengkerang Kecamatan Praya Timur Kabupaten Lombok Tengah. Penelitian ini termasuk peneltian kualitatif. Subyek Penelitian yaitu Kepala Desa, Kepala Dusun, Tokoh Agama, Tokoh Adat, Tokoh Pemuda dan Masyarakat. Metode pengumpulan data yang dipakai yaitu teknik observasi, wawancara, dan dokumentasi. Data yang diperoleh akan dianalisis dengan model interaktif. Hasil penelitian ini menunjukkan bahwa prosesi merariq masyarakat bangsawan dan masyarakat biasa meliputi tiga tahapan yaitu: Pertama, adat sebelum akad berupa Midang, Midang merupakan kunjungan secara langsung dari pihak laki-laki ke pihak perempuan dalam rangka memperdalam hubungan sekaligus mengikat hubungan pertalian yang lebih mendalam dalam bentuk pernikahan. Kedua, adat dalam proses akad meliputi rangakaian kegiatan Merariq, Mesejati/sejati, Pemuput selabar/selabar, dan Nyongkol atau nyodol. Ketiga, adat setelah akad, setelah acara sorong doe atau nyongkol dan bales lampak nae (balas bekas kaki).
\end{abstract}

\begin{abstract}
In the customs of the Sasak people, especially the descendants of the aristocracy, especially women, if they want to get married they have to find someone who is an aristocrat, otherwise their inheritance will be forfeited and will be sanctioned to leave the aristocratic class. Meanwhile, men are allowed to marry into ordinary people or noble societies. The purpose of this article is to explain the traditional procession of drawing aristocratic communities with ordinary people in Sengkerang Village, Praya Timur District, Central Lombok Regency. This research includes qualitative research. Research subjects were village heads, hamlet heads, religious leaders, traditional leaders, youth and community leaders. The data collection methods used were observation, interview and documentation techniques. The data obtained will be analyzed with an interactive model. The results of this study indicate that the merariq procession of the aristocratic society and the common people includes three stages, namely: First, the custom before the contract in the form of Midang, Midang is a direct visit from the male side to the female side in order to deepen the relationship as well as to tie a deeper relationship. form of marriage. Second, customs in the contract process include a series of Merariq activities, true / true, Pemuput patience / patience, and Nyongkol or nyodol. Third, the customs after the contract, after the sorong doe or nagging and bales lampak nae (reply to the foot marks).
\end{abstract}

\section{A. LATAR BELAKANG}

Budaya merarik yang terdapat pada masyarakat Sasak ini merupakan wujud kearifan lokal yang didaamnya terlibat suat keyakinan bagi masyarakatnya untuk menjalaninya sebagai pembuktian keberanian seorang laki-laki pada calon istrinya. Merarik merupakan adat istiadat yang memang sudah ada dan secara turun temurun telah diwariskan oleh nenek moyang terdahulu sehingga tetap dijalankan. Dalam adat istiadat masyarakat sasak terutama keturunan bangsawan khsususnya kaum perempuan, apabila ingin menikah dia harus mencari orang yang sebangsawannya, jika tidak maka harta warisan akan hangus, dan diberikan sanksi keluar dari golongan bangsawan. Sedangkan kalau laki-laki diperbolehkan menikah dengan masyarakat biasa ataupun masyarakat bangsawan. 
Penelitian yang relevan dalam penelitian ini mengacu pada penelitian yang menjelaskan rangkaian tradisi Bejango yang merupakan salah satu rangkaian acara pernikahan dalam adat Sasak sekaligus peniggalan leluhur/nenek moyang bangsa Sasak dilaksanakan melalui tahap-tahap tertentu, tradisi Bejango sendiri meruakan rangakaian acara terakhir dari acara adat pernikahan masyarakat Sasak dan menjelaskan nilai apa saja yang terkandung dalam tradisi tersebut. Upacara adat Bejango tersebut tidak pernah berubah dari dulu hingga sekarang.[1] Penelitian lainnya membahas alasan-alasan masyarakat Sasak melakukan merarik dan apa saja permasalahan yang muncul karena merarik ini, penelitian ini juga meberikan saran agar masyarakat tidak menyalahgunakan adat merarik ini utntuk kepentingan yang tidak benar.[2] Tradisi Merariq ini tidak di benarkan dalam Islam, karena proses peminangan dalam Islam dengan peminangan tradisi Merarik sangat berbeda dan tradisi ini banyak menimbulkan kemudharatan dan bertentangan dengan hukum Islam. Walaupun begitu Merarik tetap diakui sebagai status hukum karena merupakan salah satu adat istiadat[3].

Proses perkawinan pra dan akad nikah pada golongan bangsawan terlihat tradisional, kental budaya, adat istiadat dan nuasa tinggi, sementara merariq pada masyarakat biasa berjalan biasa saja. Proses merariq: midang, menculik, besejati atau berselebar, betikah, begawe, nyongkolan, bales ones naen.[4] Eksistensi perkawinan beda kasta antara bangsawan dengan masyarakat biasa dalam pandangan tokoh agama lebih menarik pada aspek adatnya karena pengaruh kebudayaan, agama, adat dan pengalaman dahulu kala.[5] Pernikahan golongan bangsawan dan non bangsawan secara hukum adat dilanggar jika tidak mengikuti adat masyarakat sasak, serta ada perbedaan status social [6];[7].

Beberapa penelitian sebelumnya lebih mengkaji pada aspek tradisi merariq dalam perkawinan sasak, mereriq dalam hukum Islam tidak dibenarkan, alasan merariq dalam masyarakat sasak, perbedaan perkawinan kasta golongan bangsawan dan masyarakat biasa dalam masyarakat sasak, pandangan tokoh agama dalam perkawinan golongan bangsawan dan non bangsawan dalam masyarakat sasak. Sedangkan aspek prosesi adat merarik masyarakat bangsawan dengan masyarakat biasa, fokus penelitian dan lokasi penelitian belum banyak yang meneliti. Oleh karena itu, artikel ini sangat penting dilakukan untuk menjelaskan secara mendalam tentang prosesi merariq antara golongan bangsawan dan masyarakat biasa dalam masyarakat sasak. Merariq bagi masyarakat sasak merupakan tradisi adat istiadat dalam melakukan perkawinan dengan cara menculik si gadis untuk dipinang menjadi pendamping hidupnya yaitu istri. Sementara daerah lain, menculik anak orang tanpa sepengetahuan keluarga merupakan perbuatan yang melanggar norma agama dan norma hukum. Namun bagi masayarakat sasak menculik atau merariq merupakan adat istiadat yang sejak lama telah berkembang hingga sekarang ini, hal menarik juga merariq juga terjadi pada golongan bangsawan atau golongan keturunan kerajaan, keturunan orang terhormat baik untuk kaum laki-laki maupun kaum perempuan.

Kenyataan yang terjadi, larangan perkawinan antara golongan bangsawan dengan masyarakat biasa sangat kental ditengah masyarakat sasak demi untuk menjaga harga diri dan martabat golongan bangsawan. Jika lakilakinya adalah seorang golongan bangsawan maka menikah dengan perempuan masyarakat biasa tidak masalah, akan tetapi jika si gadis adalah seorang dari golongan bangsawan maka diharuskan menikah dengan sesama golongan bangsawan dan jika itu dilanggar maka si gadis tersebut tidak akan mendapatkan warisan berupa harta bergerak dan tidak memiliki hak mengeluarkan pendapat dalam keluarganya. Ini terjadi karna sistem kekerabatan yang dianut oleh masyarakat Sasak adalah sisetm patrilineal, sehingga jika seorang istri dari golongan bangsawan menikah dengan laki-laki biasa maka derajatnya mengikuti suaminya serta anak yang dihasilkan dari pernikahan tersebut akan mengikuti garis keturunan bapaknya. Dalam beberapa kejadian ada juga dimana ketika seorang gadis menikah dengan laki-laki biasa maka oleh orang tuanya si gadis akan dibuang dan tak dianggap sebagai anak lagi. Keadaan semacam ini yang mengakibatkan golongan bangsawan menikah dengan orang yang masih memiliki hubungan keluarga atau endogamy, agar kebangsawanan mereka tetap terjaga.

Merariq dalam masyarakat bangsawan dan masyarakat biasa merupakan adat istiadat yang setiap kali kegiatan perkawinan selalu mengimplementasikan merariq tersebut. Secara historis merariq merupakan budaya lokal yang hidup di pulau Lombok mulai leluhur sebelumnya hingga sekarang ini. Akan tetapi pada masa sekarang ini pemikiran semacam itu sudah sedikit memudar karena perkembangan zaman yang lebih modern dan tingkat pendidikan yang maju.

Jadi prosesi merariq dalam masyarakat sasak meliputi beberapa rangkaian kegiatan yaitu midang (seorang laki-laki datang mengunjungi rumah wanita/gadis yang menjadi kekasihnya), menculik (membawa lari gadis), besejati atau berselebar (proses menyampaikan informasi yang ditujukan kepada pemerintah desa (desa asal calon pengantin wanita) untuk memberitahukan kepada kepala desa (Pengamong Krame) kemudian dilanjutkan informasi tersebut kepala dusun atau keliang (Pengemban Krame)), sorong serah (suatu dorongan kepada kedua orang tua pengantin untuk menyerahkan atau melepaskan (Serah Terima) anak mereka untuk hidup berumah tangga sehingga kedua pengantin tidak terikat pada orang tua mereka 
masing masing), begawe (pesta), nyongkolan (arakarakan kedua mempelai laki-laki dan perempuan di jalan), bales ones naen (kembali untuk bersilaturrahmi).

Dalam pelaksanaanya tradisi merariq masyarakat bangsawan dan masyarakat biasa dapat multitafsir, mengingat secara hukum islam bertentangan, namun secara kultural justru memiliki makna yang luas yang mempunyai nilai social, budaya dan ekonomi. Dalam konteks kultural atau kebudayaan memiliki wujud berupa: wujud ideal kebudayaan yaitu sifatnya abstrak, tak dapat diraba dan difoto. Sistem Sosial atau sosial sistem, yaitu mengenai tindakan beberapa manusia itu sendiri. Kebudayaan fisik, yaitu seluruh hasil fisik karya manusia dalam masyarakat. Sifatnya sangat konkrit berupa benda-benda yang bisa diraba, difoto dan dilihat [8]. Karena memiliki kultural yang mendalam inilah banyak pengembangan keilimuan yang dicapai dalam perkawinan merariq masyarakat bangsawan dan masyarakat biasa. Focus kajian dalam artikel ini menjelaskan prosesi adat merarik masyarakat bangsawan dengan masyarakat biasa di Desa Sengkerang Kecamatan Praya Timur Kabupaten Lombok Tengah.

Pelapisan sosial dikalangan suku sasak terbagi menjadi tiga golongan yaitu : (1) golongan menak, (2) golongan pruangse dan (3) golongan jajar karang. [9] Sistem perkawinan suku sasak, ketika sudah terjadi perkawinan maka itu berarti berlakunya ikatan kekerabatan yang rukun dan damai. Dikarenakan nilai hidup yang menyangkut tujuan perkawinan dan kehormatan keluarga dalam pergaulan masyarakat, pemuka agama dan pemuka adat.[10] Merarik atau menikah adalah istilah yang dipakai untuk keseluruhan sistem perkawinan masyarakat Sasak Lombok, istilah ini digunakan dalam setiap komunitas masyarakat diseluruh pulau Lombok. Praktik merarik merupakan sistem adat pernikahan yang masih diterapkan di Lombok. Dalam konteks keabsahan kawin lari jika dikaitkan dalam adat tardisi Suku Sasak, bukanlah kawin lari kebanyakan pada masyarakat umum yang tidak direstui orang tua mereka sehingga memilih kawin lari utnuk mengikat hubungan mereka. Akan tetapi pada tradisi masyarakat Sasak kawin lari yang dimaksud adalah sebuah proses adat.[11]

\section{B. METODE PENELITIAN}

Penelitian ini termasuk peneltian kualitatif. Penelitian ini bertujuan menguraikan fakta, peristiwa dan perilaku masyrakat yang berkaitan dengan merarik. Subyek Penelitian ini terdiri atas: Kepala Desa, Kepala Dusun, Tokoh Agama, Tokoh Adat, Tokoh Pemuda dan Masyarakat yang terlibat langsung dengan tradisi merarik. Metode pengumpulan data yang digunakan dalam penelitian ini adalah teknik observasi, wawancara, dan dokumentasi. Setelah diperoleh dan dikumpulkan maka dilakukan analisis data dengan cara kualitatif.
Dimana data yang diperoleh di lapangan akan dreduksi, disajikan dan kemudian ditarik kesimpulan.

\section{HASIL DAN PEMBAHASAN}

\section{Prosesi adat merarik masyarakat bangsawan dengan masyarakat biasa}

Mengenai proses adat merarik masyarakat bangsawan dengan masyarakat biasa di desa sengkerang, beberapa informan memberikan pernyataannya, informan yang pertama bapak Lalu Awaludin selaku kepala desa

Merarik ato maling artin proses melaikang nine isik calon semame terus tesebok arak semalem lekn bale keluarge penganten mame ato bale sak wah tetentuan sik penganten mame seendekman merarik ato memaling, sekaliwah jari proses awal seendekman acare akad nikah." (merarik atau kawin lari merupakan proses melarikan perempuan atau alon istri oleh laki-laki lalu menyembunyian sehari di rumah salah satu keluaraga atau kerabat yang sudah ditentukan sebelumnya sekaligus menjadi proses awal akad nikah) (wawancara tanggal 4 mei 2020)

Informan kedua Bapak H. Zainal Arifin selaku kepala dusun Sengkerang 3

prosesi perkawinan sak berlaku lek masyarakat sasak ye teselesaian sesuai kance ktentuan adat sak berlaku lek dise masingg-masing, adat pelaksanaan perkawinan sak telaksanaan bedoe telu tahapan, yaitu : adat seendekman akad, adat pas sak proses akad, adat seuwah akad (prosesi adat merarik masyarakat bangsawan dengan masyarakat biasa mempunyai tiga tahapan yaitu : adat sebelum akad, adat dalam proses akad, adat setelah akad). (wawancara pada tanggal 7 Mei 2020)

Informan ketiga H. Sudirman Arafah selaku Tokoh Adat

Proses adat merarik bangsawan kance mayarakat biase ye bedoe tahapan, tahapan arak telu, yaitu : Adat seendekman akad, adat sak nyengke proses akad dait dat setelah akad. Adekn bau lebih jelas bau tejelasan tahapan sak te kene (prosesi adat merarik masyarakat bangsawan dengan masyarakat biasa mempunyai tiga tahapan yaitu : adat sebelum akad, adat dalam proses akad, adat setelah akad. untuk lebih jelasnya tahapan yang di maksud yaitu) :

1. Adat seendakman tekawin sak terdiri elek: Midang, midang nu mame dateg jok bale nine dalem rangke memperdalam hubungan dalem bentuk pernikahan. (adat sebelum akad terdiri dari dari (midang/ngapel yang merupakan kunjungan secara langsung pihak laki-laki untk pihak perempuan dalam rangka meperdalam hubungan sekaligus mengikat hubungan pertalian yang lebih mendaam dalam bentuk pernikahan)

2. Adat sak nyengken proses tekawin, sak pertame: merarik ato memaling nu proses melaiqan nine atau calon senine isik mame terus lalo tesebok sejelo lek salak sekek bale keluarge 
ato lek bale dengan sak wah tentuan sik calon penganten. Sak kedue: Sejati, Sejati nu kegiatan pertame sak tegawek isik pihak keluarge mame seuwah sak nine mauk tejauk pelai atau melaiqan sak yak tejarian senine atau pendampingan irup sak mame. Sejati tegawek isik aparat dese sak arak lek lingkungan calon pengangten sak mame paling telat due jelo elek jelo merarik. Sak ketelu : Selabar, Selabar nu pengebeng atau lalo bebarak kepastian sengak arak terjadi perkawinan ato pelarian isik due dengan sak saling bekemelekan sak melanjutkan hubungan ke jenjang pernikahan. Sak keempat: Nyongkol atau nyodol Nyongkol atau nyodol nu acare terakhir elek selapuk rangkaian adat pernikahan. Rangkaian sak ji telaksanaan sik selapuk warge pihak mame dait selapuk warge masyarakat dese, kance memepelai sak mame tinggal berkunjung jok bale penganten nine. (adat dalam proses akad merarik/melaiqan merupakan proses melarikan si perempuan atau calon istrinya oleh si laki-laki calon suaminya lalu menyembunyikan dirumah keluarga atau rumah orang yang sudah di tentukan. Yamg kedua : sejati merupakan kegiatan yang pertama yang dilakukan oleh pihak laki-laki setelah siperempuan berhasil dilatikan untuk dijadikan istri atau pendamping hidup lak-laki. Sejati atau laporan dilaksanakan oleh aparat desa yang ada dilingkungan calon mempelai laki-laki paling lambat dua hari dari hari melarikannya. Yang ketiga : selabar merupakan pemberian informasi akan kepastian dua orang saling suka untuk selanjutnya sepakat melanjutkan hubungan ke jenjang perkinakahan. Yang keempat : nyongkol atau nyodol merupakan kegiatan teraakhir dari selurh rangkaian proses adat pernikahan, rangkaian ini dilakasanakan oleh seluuh keluarga pihak lak-laki dengan masyarakat dusun setempat dan mempelai lakilaki tinggal berkunjung kerumah mempelai perempuan).

3. Adat seuwah tekawin nu Seuwah acare sorong doe atau nyongkol arak pire acare adat sak harus tegawek. Upacare sak tegawek setelah acare nyongkolan aran bales lampak nae, bales lampak nae nu salah sekek kegiatan silaturahmi lek pihak keluarge penganten mame jok pihak keluarge penganten nine khsusus keluarge penganten mame ndk perlu milu lanting masyarakat marak ntan sak lalo nyongkolan "(setelah acara sorong doe atau nyongkol dilakukan maka aka nada beberapa upacara adat yang harus dolaksanakan setelah proses pernikahan yaitu bales lampak nae (balas bekas kaki), bales lampak nae merupakan salah satu kegiatan kunjungan dari pihak pengantin laki-laki ke pohak keluarga pengantik perempuan tanpa mengikutsertakan warga masyarakat seperti pada acara nyongkolan).

Proses merarik masyarakat bangswan kance masyarakat biase pade entan kadu adat merarik laguk arak ntan lain tetengat elek payung agung dait pakean sak tekadu pas nyongkolan, laguk nani wah pade daong ntan timak masyarakat bangsawan dait ,asyarakat biase.
Perbedaan sak masih tedait nani lek aji krame (proses pernikahan masyarakat biasa dengan bangsawan sama saja tapi perbedaannya terletak pada payung agung dan pakaian yang digunakan disaat acara nyongkolan, tapi sekarang sudah hampir sama dari masyarakat bangsawan denngan masyarakat biasa, perbedaan yang masih bisa dilihat pada masa sekarang ini trletak pada aji krame nya saja.

Lamun kaum bangsawan mame dait masyarakat biase nine merarik, sak nine nurutan jok sak mame milu jari bangsawan. Laguk lamun bangsawan nine dait masyarakat biase mame merarik menurut adat ndekne kangoo, laguk lamun tetep mele lanjutan merarik maka arak sanksi adat yakne mauk marak sak nine teteteh sik dengan toak, tetacuhan sik keluarge dait ndekne mauk harte warisan (jika kaum bangsawan laki-laki dengan wantita dari masyarakat biasa menikah, maka wanita akan mengikuti garis keturunan laki-laki. Tetapi ika wnita dari golongan bangsawan menikah dengan laki-laki dari masyarakat biasa maka tidak diperbolehkan tapi jika pernikahan tetap dilanjutkan maka akan dikenakan sanksi adat berupa wanita akan di buang oleh keluarga tidak diakui lagi menjadi anak, diacuhkan oleh keluarga dan tidak akan mendapatkan harta warisan). (wawancara pada tanggal 8 mei 2020)

\section{Informan keempat amaq Ismail (tokoh Agama)}

"Mengenai proses adat merarik masyarakat bangsawan kance masyarakat biase, arak persamaan kance arak perbedaan laguk sak jari perbedaan nu aji krame lamun degan bangsawan aji krame ara 66 selakse lamun masyarakat biase arak 33 selakse. Sejati merupakan laporan langan pihak mame jok pihak aparat pemerintah, sedangkan selabara adalah laporan langan pihak mame jok pihak sak nine, abaik diterima atau endek, endah lamun mame bangsawan merarik kance masyarakat biase maka harus tegawek sejati kance selabar selebihnya tetep pade proses adat baik masyarakat bangsawan dait masyarakat biase" (mengenai proses adat merarik masyarakat bangsawan dengan masyarakat biasa, ada persamaan dan perbedaannya yang menjadi pembeda adalah di aji krame nya sebesar 66 selakse sedangkan masyarakat biasa nilaanya 33 selakse. Sejati merupakan laporan dari merupakan laporan dari pihak laki-laki kepada keluarga pihak perempuan, baik diterima maupun tidak diterima dan apabila laki-lakinya bangsawan dan perempuan dari masyarakat biasa mak terap harus dilaksanakan sejati dan selabar, selebihnya selebihnya tetap sama prosesi adatnya baik bangsawan maupun non bangsawan). (wawancara pada tanggal 11 Mei 2020)

Berdasarkan uraian diatas dapat di simpulkan bahwa merarik atau kawin lari merupakan proses melarikan perempuan atau calon istrinya oleh laki-laki calon suaminya lalu menyembunyikan sehari di salah satu rumah keluarga laki-laki atau rumah salah satu 
kerabat yang sudah di tentukan sebelumnua. Sekaligus menjadi proses awal akad nikah akan tetapi jugayang menikah dengan cara meminang tetapi sangat kurang sekali yang menikah dengan cara meminang.

Prosesi perkawinan yang berlaku di masyarakat Sasak yang diselesaikan sesuai dengan ketentuan adat yang berlaku di desa masing-masing. Adat pada pelaksanaan perkawinan Sasak di desa Sengkeranng yang dilakukan ini mempunyai tiga tahapan, yaitu: adat sebelum akad, adat dalam proses akad dan adat setelah proses akad. Yang pertama adat sebelum proses akad meliputi yaitu : midang, midang merupakan kunjungan secara langsung dari pihak laki-laki ke pihak perempuan dalam rangka memperdalam hubungan sekaligus mengikat hubungan pertalian yang lebih mendalam dalam bentuk pernikahan. Yang kedua : adat daalam proses akad yang meliputi (1) merarik, Merarik merupakan proses melarikan si perempuan atau calon istrinya oleh si laki-laki calon suaminya lalu menyembunyikan disalah satu rumah yang sudah ditentukan, setelah itu baru dilakukan proses selanjutnya, (2) mensejati/sejati, Sejati merupakan prosesi yang pertama yang dilakukan oleh pihak keluarga laki-laki sejati atau laporan dilaksanakan oleh aparat desa yang dilingkungan calon mempelai lakii-laki paling lambat dua hari dua malam dari hari melarikan. (3) selabar/pemuput selabar, Selabar merupakan pemberi informasi dari pihak keluarga calon pengantin laki-laki akan kepastian bahwa telah terjadi pernikahan atau pelarian oleh dua orang yang saling suka untuk selanjutnya sepakat melanjutkan hubungan ke jenjang pernikahan, dan yang terakhir (4) nyongkol atau nyodol merupakan kegiatan terakhir dari selurh rangkaian proses adat pernikahan, rangkaian ini dilakasanakan oleh seluruh keluarga pihak lak-laki dengan masyarakat dusun setempat dan mempelai laki-laki tinggal berkunjung kerumah mempelai perempuan. Yang keiga Adat setelah pernikahan, setelah acara sorong doe atau nyongkol dilakukan maka akan ada beberapa upacara adat yang harus dolaksanakan setelah proses pernikahan yaitu bales lampak nae (balas bekas kaki), bales lampak nae merupakan salah satu kegiatan kunjungan dari pihak pengantin laki-laki ke pihak keluarga pengantik perempuan tanpa mengikutsertakan warga masyarakat seperti pada acara nyongkolan.

Sama halnya dengan perkawinan yang dilakukan oleh para bangsawan dengan masyarakat biasa memiliki perbedaan-perbedaan, walaupun adat yang diunakan dalam perkawinan sma-sama menggunakan adat merarik atau memaling. Salah satu perbedaan itu terlihat dari payung agung yang biasanya digunakan oleh para bangsawan saat acara nyongkolan. Penggunaan paying agung tersebut sebagai tanda bahwa mereka adalah seorang bangsawan sedangkan masyarakat biasa tidak menggunakan payung agung.

Pada zaman dahulu para bangsawan dalam perkawinannya menggunakan pakaian adat yang berupa kain tenun Sasak yang dibentuk seperti kemben pakaian sebatas dada yang diamana laki-laki hanya sebatas dengkul atau biasa disebut dodot serta sebuah keris yang diselipkan di antara dodot dan dilengkapikan diantara dodot dan dilengkapi dengan sapuk yaitu tutup kepala dengan motif tertentu. Sedangkan perempuannya juga menggunakan kemben akan tetapi samapi mata kaki. pada masyarakat biasa juga menggunakan dodot akan tetapi diluarnya menggunakan kebaya dan kain songket sebagai bawahannya. Diantara perbedaan tersebut hal yang palin membedakan perkawinan pada masyarakat bangsawan dengan masyarakat biasa adalah aji krame yang dibacakan saat sorong serah.

Dari golongan menak perkawinan bertujuan untuk mempertahankan status sosial, maka dengan tujuan ini mereka tidak menghendaki perkawinan dengan masyarakat biasa. jika kaum bangsawan laki-laki dengan wantita dari masyarakat biasa menikah, maka wanita akan mengikuti garis keturunan laki-laki. Tetapi ika wanita dari golongan bangsawan menikah dengan laki-laki dari masyarakat biasa maka tidak diperbolehkan tapi jika pernikahan tetap dilanjutkan maka akan dikenakan sanksi adat berupa wanita akan di buang oleh keluarga tidak diakui lagi menjadi anak, diacuhkan oleh keluarga dan tidak akan mendapatkan harta warisan. Akibat dari perlakuan iniseseorang yang berasal dari masyarakat biasa akan berfikir ulang untuk menikahi perempuan yang berasal dari golongan bangsawan karena akan mendapatkan kesulitan dalam hubungan kekerabatan di kemudian hari.

Akan tetapi perbedaan-perbedaan di atas pada masa sekarang ini adalah tidak bisa terlihat lagi. Pada masa sekarang ini baik itu perkawinan yang dilakukan golongan bangsawan maupun masyarakat biasa dalam prosesnya tidak bisa dibedakan mana yang bangsawan dan masyarakat biasa. Pada saai ini dari golongan mana saja mengunakan payung agung sebagai pelengkap ketika dalam proses nyongkolan dilaksanakan. Sedangkan dalam hal berpakaian sekarang sudah tidak ada yang menggunakan kemben. Akan tetapi yang masih bisa membedaka antara perkawinan golongan bangswan dengan maasyarakat biasa adalah pada besa aji krame yang disebutkan dalam prosesi sorong serah. Jika dari golongan raden nilainya 100, kalau dari lalu/baiq nilainya sebesar 66 dan dari masyarakat biasa nilainya 33 .

Merarik atau kawin lari merupakan proses melarikan perempuan atau calon istri oleh laki-laki calon suami lalu disembunyikan selama sehari di rumah keluarga laki-laki atau salah satu rumah yang sudah di tentukan sebelumnya. Sekaligus menjadi proses awal akad nikah akan tetapi ada juga yang menikah dengan cara meminang tetapi sangat kurang sekali yang menikah dengan cara meminang.

Prosesi perkawinan yang berlaku di masyarakat Sasak yang di selesaikan sesuai dengan ketentuan adat yang berlaku di desa masing-masing. Adat pada 
Pelaksanaan perkawinan Sasak yang dilaksanakan ini mempunyai tiga tahapan yaitu :

1. Adat sebelum akad yaitu Midang

Midang merupakan kunjungan secara langsung dari pihak laki-laki ke pihak perempuan dalam rangka memperdalam hubungan sekaligus mengikat hubungan pertalian yang lebih mendalam dalam bentuk pernikahan.

2. Adat dalam proses akad meliputi:

a) Merarik

Merarik merupakan proses melarikan si perempuan atau calon istrinya oleh si laki-laki calon suaminya lalu menyembunyikan disalah satu rumah yang sudah ditentukan, setelah itu baru dilakukan proses selanjutnya

b) Mesejati/sejati

Sejati merupakan prosesi yang pertama yang dilakukan oleh pihak keluarga laki-laki sejati atau laporan dilaksanakan oleh aparat desa yang dilingkungan calon mempelai lakii-laki paling lambat dua hari dua malam dari hari melarikan.

c) Pemuput selabar / selabar

Selabar merupakan pemberi informasi akan kepastian bahwa telah terjadi pernikahan atau pelarian oleh dua orang yang saling suka untuk selanjutnya sepakat melanjutkan hubungan ke jenjang pernikahan

d) Nyongkol atau nyodol

Nyongkol atau nyodol merupakan kegiatan teraakhir dari selurh rangkaian proses adat pernikahan , rangkaian ini dilakasanakan oleh seluuh keluarga pihak lak-laki dengan masyarakat dusun setempat dan mempelai laki-laki tinggal berkunjung kerumah mempelai perempuan.

3. Adat setelah akad

Setelah acara sorong doe atau nyongkol dilakukan maka aka nada beberapa upacara adat yang harus dolaksanakan setelah proses pernikahan yaitu bales lampak nae (balas bekas kaki), bales lampak nae merupakan salah satu kegiatan kunjungan dari pihak pengantin laki-laki ke pohak keluarga pengantik perempuan tanpa mengikutsertakan warga masyarakat seperti pada acara nyongkolan.

Sama halnya dengan perkawinan yang dilakukan oleh para bangsawan dengan masyarakat biasa memiliki perbedaan-perbedaan, walaupun adat yang diunakan dalam perkawinan sma-sama menggunakan adat merarik atau memaling. Salah satu perbedaan itu terlihat dari payung agung yang biasanya digunakan oleh para bangsawan saat acara nyongkolan. Penggunaan paying agung tersebut sebagai tanda bahwa mereka adalah seorang bangsawan sedangkan masyarakat biasa tidak menggunakan payung agung.

Pada zaman dahulu para bangsawan dalam perkawinannya menggunakan pakaian adat yang berupa kain tenun Sasak yang dibentuk seperti kemben pakaian sebatas dada yang diamana laki-laki hanya sebatas dengkul atau biasa disebut dodot serta sebuah keris yang diselipkan di antara dodot dan dilengkapikan diantara dodot dan dilengkapi dengan sapuk yaitu tutup kepala dengan motif tertentu. Sedangkan perempuannya juga menggunakan kemben akan tetapi samapi mata kaki. pada masyarakat biasa juga menggunakan dodot akan tetapi diluarnya menggunakan kebaya dan kain songket sebagai bawahannya. Diantara perbedaan tersebut hal yang palin membedakan perkawinan pada masyarakat bangsawan dengan masyarakat biasa adalah aji krame yang dibacakan saat sorong serah.

Dari golongan menak perkawinan bertujuan untuk mempertahankan status sosial, maka dengan tujuan ini mereka tidak menghendaki perkawinan dengan masyarakat biasa. jika kaum bangsawan laki-laki dengan wantita dari masyarakat biasa menikah, maka wanita akan mengikuti garis keturunan laki-laki. Tetapi ika wanita dari golongan bangsawan menikah dengan laki-laki dari masyarakat biasa maka tidak diperbolehkan tapi jika pernikahan tetap dilanjutkan maka akan dikenakan sanksi adat berupa wanita akan di buang oleh keluarga tidak diakui lagi menjadi anak, diacuhkan oleh keluarga dan tidak akan mendapatkan harta warisan. Akibat dari perlakuan iniseseorang yang berasal dari masyarakat biasa akan berfikir ulang untuk menikahi perempuan yang berasal dari golongan bangsawan karena akan mendapatkan kesulitan dalam hubungan kekerabatan di kemudian hari.

Akan tetapi perbedaan-perbedaan diatas pada masa sekarang ini adalah tidak bisa terlihat lagi. Pada masa sekarang ini baik itu perkawinan yang dilakukan golongan bangsawan maupun masyarakat biasa dalam prosesnya tidak bisa dibedakan mana yang bangsawan dan masyarakat biasa. Pada saai ini dari golongan mana saja mengunakan paying agung sebagai pelengkap ketika dalam proses nyongkolan dilaksanakan. Sedangkan dalam hal berpakaian sekarang sudah tidak ada yang menggunakan kemben. Akan tetapi yang masih bisa membedaka antara perkawinan golongan bangsawan dengan masyarakat biasa adalah pada besar aji krame yang disebutkan dalam prosesi sorong serah. Jika dari golongan raden nilainya 100, kalau dari lalu/baiq nilainya sebesar 66 dan dari masyarakat biasa nilainya 33 .

\section{Makna Merarik bagi masyarakat bangsawan dan masyarakat biasa di desa Sengkerang Kecamatan Praya Timur}

Mengenai makna merarik bagi masyarakat bangsawan di desa Sengkerang, bebrapa informan ataupun narasumber memberikan pernyataanya. informan pertama Lalu Awaludin selaku Kepala Desa mengatakan

Makne merarik masyarakat bangsawan bagi nie nu aden sak tetep jagak keturunan aden sak tetep tehormati endah lek kalangan masyrakat biase. (makna merarik (pernikahan) bagi masyarakat 
bangsawan yang terdapat didalamnya adalah untuk menjaga terarahnya atau nasabnya dan menjaga keturunannya dan semakin di hormati di kalangan masyarakat biasa). (wawanacara mnegtakan pada tanggal 4 mei 2020 )

Informan kedua bapak H. Zainal Arifin

Makne merarik kance pade masyarakat biase nu nendek teriket sik gelar kebangsaan jari proses merarik nu biase-base endek terlalu teriket sik aturan adat istiadat. (Makna merarik (pernikahan) sesama masyarakat biasa yaitu pernikahan yang terjadi sesama masyarakat biasa tidak terikat dengan gelar kebangsawanan sehingga ketika proses pernikahan yang dilakukan oleh kalangan biasa itu bisa selesai dengan proses pernikahan yang biasa-biasa). (wawancara pada tanggal 7 Mei 2020)

Berdasarkan hasil wawancara yang dilakukan, dapat disimpulkan bahwa makna merarik (pernikahan) bagi masyarakat bangsawan ataupun sesama bangsawan yang didalamnya adalah agar tetap hormati oleh kalangan masyarakat biasa karena ketika pernikahan yang dilakukan oleh kalangan bangsawan akan membuat tinggi derajat sosialnya, dan diikuti oleh prosesi suatu proses pernikahannya yang mengandung nuansa tradisional suku Sasak.

Adapun sebagai pendukung kesuksesan secara pernikahan sesama bangsawan yaitu : pertama karena sesama bangsawan pernikahan akan menjadikan mereka semakin dihormati oleh masyarakat. Kedua, adanya kemampuan dalam segi financial ekonomi dan ketiga yaitu adanya dukungan orang tua.

Makna merarik (pernikahan) bagi masyarkat biasa atau yang menikah sesama masyarakat biasa yaitu ketika pernikahan sesama masyarakat biasa yang bukan golongan bangsawan, maka pernikahan yang dilakuakan dengan prosesi yang biasa-biasa saja tidak seperti masyarakat bangsawan yang harus mengikuti tata adat istiadat suku Sasak khususnya di desa Sengkerang, ketika menikah terdapat makna yaitu : pernikahan sesama masyarakat biasa tidak terikat dengan gelar kebangsawanan sehingga ketika poses yang dilakukan oleh kalangan biasa itu bisa selsesai dengan proses pernikahan yang biasa saja tidak terlalu terikat dengan aturan-aturan adat istiadat. Dan adanya dukungan orang tua, hal ini desebabkan karena orang tua sangat berpengaruh ketika pernikahan anaknya, banyak dari kalangan orang tua yang tidak menyetejui anaknya menikah karena jika anaknya menikah dengan bangsawan sedangkan anaknya masyarakat biasa, itu akan menjadikan anaknya selalu diremehkan oleh kalangan yang memiliki gelar bangsawan.

Makna merarik (pernikahan) bagi masyarakat bangsawan ataupun sesama bangsawan yang didalamnya adalah semakin di hormati oleh kalangan masyarakat biasa karena ketika pernikahan yang dilakukan oleh kalangan bangsawan akan tinggi derajat sosialnya, dan diikuti oleh prosesi suatu proses pernikahannya yang mengandung nusansa tradisional suku Sasak yakni akad nikah akan dilaksanakan di rumah pengantin wanita, proses yang dilakukan selanjutnya adalah begawe (pesta) dan nyongkolan, proses pernikahan akan dilakukan proses aji krame dan sorong serah. sedangkan apabila perkawinan terjadi antara perempuan bangsawan dengan laki-laki non bangsawan, maka tidak ada proses begawe dan nyongkolan yang ada hanya roah jamak-jamak (makan bersama yang dilakukan dirumah si laki-laki bersama orang-orang yang sekampung dengannya).

Adapun sebagai pendukung kesuksesan acara pernikahan sesama bangsawan, Pertama, Pernikahan sesama bangsawan akan menjadikan mereka semakin dihormati oleh masyarakat. Kedua, Agar harta warisan tidak berpindah ke kelurga lain sehingga dengan menikah sesama bangsawan akan membuat harta warisan tetap di milki keluarga/sesama bangsawan. Ketiga, Adanya dukungan orang tua. Hal ini karena orang tua berpengaruh dalam pernikahan anaknya, banyak orang tua yang ingin anaknya hanya menikah dengan sesama bangsawan untuk menjaga kedudukan istimewa yang dimilikinya dari keturunan yang berasal dari nenek moyang terdahulu yang memiliki derajat lebih tinggi dari masyarakat biasa.

Makna merarik (pernikahan) bagi masyarkat biasa atau yang menikah sesama masyarakat biasa yaitu ketika pernikahan sesama masyarakat biasa yang bukan golongan bangsawan, maka pernikahan yang dilakuakan dengan prosesi yang biasa-biasa saja tidak seperti masyarakat bangsawan yang harus mengikuti tata adat istiadat suku Sasak khususnya di desa Sengkerang , ketika menikah terdapat makna yaitu :

Pertama, Pernikahan sesama masyarakat biasa tidak terikat dengan gelar kebangsawanan sehingga ketika poses yang dilakukan oleh kalangan biasa itu bisa selsesai dengan proses pernikahan yang biasa saja tidak terlalu terikat dengan aturan-aturan adat istiadat suku Sasak.

Kedua, Adanya dukungan orang tua. Hal ini desabkan karena orang tua sangat berpengaruh ketika pernikahan anaknya, banyak dari kalangan orang tua yang tidak menyetejui anaknya menikah karena jika anaknya menikah dengan bangsawan sedangkan anaknya masyarakat biasa, itu akan menjadikan anaknya selalu diremehkan oleh kalangan yang memiliki gelar bangsawan.

\section{TEMUAN ATAU DISKUSI}

Prosesi merariq masyarakat bangsawan dan masyarakat biasa tetap berlaku ketentuan adat yang berlaku di desa masing-masing. Adat pada Pelaksanaan perkawinan Sasak baik perkawinan golongan bangsawan dan masyarakat biasa yang dilaksanakan tiga tahapan yaitu :

Tahap Pertama, adat sebelum akad berupa Midang, Midang merupakan kunjungan secara langsung dari pihak laki-laki ke pihak perempuan dalam rangka 
memperdalam hubungan sekaligus mengikat hubungan pertalian yang lebih mendalam dalam bentuk pernikahan.

Tahap Kedua, adat dalam proses akad meliputi rangakaian kegiatan Merariq, Mesejati/sejati, Pemuput selabar/selabar, dan Nyongkol atau nyodol. Merarik merupakan proses melarikan si perempuan atau calon istrinya oleh si laki-laki calon suaminya lalu menyembunyikan disalah satu rumah yang sudah ditentukan, setelah itu baru dilakukan proses selanjutnya. Sejati merupakan prosesi yang pertama yang dilakukan oleh pihak keluarga laki-laki sejati atau laporan dilaksanakan oleh aparat desa yang dilingkungan calon mempelai lakii-laki paling lambat dua hari dua malam dari hari melarikan. Pemuput selabar / selabar. Selabar merupakan pemberi informasi akan kepastian bahwa telah terjadi pernikahan atau pelarian oleh dua orang yang saling suka untuk selanjutnya sepakat melanjutkan hubungan ke jenjang pernikahan. Nyongkol atau nyodol. Nyongkol atau nyodol merupakan kegiatan teraakhir dari selurh rangkaian proses adat pernikahan, rangkaian ini dilakasanakan oleh seluuh keluarga pihak lak-laki dengan masyarakat dusun setempat dan mempelai lakilaki tinggal berkunjung kerumah mempelai perempuan.

Tahap Ketiga, adat setelah akad, setelah acara sorong doe atau nyongkol dilakukan maka aka nada beberapa upacara adat yang harus dolaksanakan setelah proses pernikahan yaitu bales lampak nae (balas bekas kaki), bales lampak nae merupakan salah satu kegiatan kunjungan dari pihak pengantin laki-laki ke pohak keluarga pengantik perempuan tanpa mengikutsertakan warga masyarakat seperti pada acara nyongkolan.

Tahapan kegiatan prosesi merariq masyarakat bangsawan dan masyarakat biasa sejalan dengan pendapat bahwa masyarakat suku Sasak adalah penduduk asli dan kelompok etnis mayoritas yang mendiami pulau Lombok. Dalam masyarakat Sasak, dikenal sistem stratafikasi sosial yang ditandai dengan gelar tertentu di awal nama mereka. Ada tiga tingakatan yang terdapat dalam sistem statafikasi sosial Sasak, yaitu; golongan bangsawan menak atas /perwangse yang berasal dari keturunan raja, yang bergar raden dan dinda. Golongan bangsawan menak menengah yang berasal dari perkawinan campuran antara laki-laki menak atas dengan perempuan jajar karang yang bergelar Gelar lalu dan lale atau baiq. Dan golongan jajar karang atau rakyat biasa dan tidak memiliki gelar khusus. Dalam adat tradisi pernikahan Sasak yang disebut merarik, ia dilakukan melalui tahapan-tahapan ketentuan adat yang meliputi: proses perkenalan dan pemilihan jodoh, dan lari bersama untuk merarik dan proses penyelaiannya serta aqad perkawinannya. Pertama, tahap perkenalan dan pemilihan jodoh melalui lembaga adat yang disebut midang. Jika masing-masing pihak sudah merasa tertarik, maka terjadilah hubungan asmara yang disebut beberayean atau bekemelean (berpacaran).

Kedua, melaiang dan proses penyelesaiannya. Dengan terjadinya merarik, berbagai tindakan adat yang mengarah pada terjadinya perkawinan mulai dilakukan oleh kedua mempelai. Tindakan tersebut meliputi: sejati (pemberitahuan kepada pihak keluarga perempuan bahwa anaknya dilarikan untuk dinikahi), selabar (permintaan izian dari keluarga si laki kepada keluarga si perempuan untuk dinikahkan, disertai dengan pembahan adat, ajikraman, pisuke) dan ngawinang (aqad nikah). Terakhir adalah upacara perkawinan yang meliputi sorong serah pembayunan dan nyongkolan. Sorong serah merupakan suatu seremoni perkawinan adat yang diadakan untuk memberikan dan menyerahkan aji krama serta benda-benda pelanggaran adat. Aji krama merupakan simbolisasi dari tingkat status sosial kedua mempelai, terutama mempelai perempuan serta anak keturunan yang dilahirkannya. Setelah seremoni sorong serah dan pembayunan selesai, selanjutnya diakhiri dengan upacara nyongkolang.[12];[13]

Merariq masyarakat golongan bangsawan dengan masyarakat biasa baik laki-laki maupun perempuan tidak menjadi halangan, karena kedua pasangan calon tersebut terikat dnegan rasa cinta, kecantikan dan kegaghan sehingga mereka tidak mempedulikan status sosial. Selain itu, karena pengaruh teknologi dan informasi yang canggih. Berdasarkan informan yang ditemukan, pelaku seperti seorang perempuan merupakan golongan bangsawan perempuan menikah dengan laki-laki masyarakat biasa telah terjadi dan dilakukan secara adat sasak.

Hal tersebut sependapat dengan temuan yang menjelaskan perkawinan beda kelas menurut fiqh munâkahât yang terjadi di internal masyarakat Muslim Sasak Lombok tidak bertentangan dengan hukum perkawinan Islam yang ada. Dalam fiqh munâkahât mensyaratkan apabila seseorang ingin mencari calon pasangan hidup yang perlu dilihat adalah nasab, kecantikan, kekayaan dan agamanya. Selain itu juga dalam fiqh munâkahât memberikan larangan yang tegas apabila seseorang ingin menikahi mahramnya. Tidak ada larangan untuk menikahi orang yang berbeda status sosial atau memiliki kedudukan yang tinggi dalam struktur kehidupan bermasyarakat.[14];[15]

\section{E. SIMPULAN DAN SARAN}

Hasil penelitian ini menunjukkan bahwa prosesi merariq masyarakat bangsawan dan masyarakat biasa meliputi tiga tahapan yaitu: Pertama, adat sebelum akad berupa Midang, Midang merupakan kunjungan secara langsung dari pihak laki-laki ke pihak perempuan dalam rangka memperdalam hubungan sekaligus mengikat hubungan pertalian yang lebih mendalam dalam bentuk pernikahan. Kedua, adat dalam proses akad meliputi 
rangakaian kegiatan Merariq, Mesejati/sejati, Pemuput selabar/selabar, dan Nyongkol atau nyodol. Ketiga, adat setelah akad, setelah acara sorong doe atau nyongkol dan bales lampak nae (balas bekas kaki).

Dengan demikian menyarankan kepada pemerintah untuk melestarikan kebudayaan lokal disesuaikan denga peruntukan dan kegunaan. Pemangku adat untuk melakukan revitalisasi hukum adat agar meniadakan unsur kasta pada masyarakat sasak pada aspek perkawinan.

\section{UCAPAN TERIMA KASIH}

Penulis mengucapkan terima kasih kepada kepala desa, tokoh adat serta LPPM UMMAT yang senantiasa memberikan dukungan dana dan sarana dan prasarana penelitian kepada penulis sehingga penelitian ini selesai dengan baik.

\section{DAFTAR RUJUKAN}

[1] M. Z. Mustamiin and S. H. Samsul, "Tradisi Bejango Dalam Perkawinan Masyarakat Sasak Di Desa Sengkerang Kecamatan Praya Timur Kabupaten Lombok Tengah," Transform. J. Penelit. dan Pengemb. Pendidik. Non Form. Informal, vol. 3, no. 2, 2017.

[2] M. Tahir, “Tradisi 'Merariq'(Kawin Lari) Dalam Masyarakat Sasak (Sebuah Telaah Konsepsi, Responsi dan Implikasi)," Harga Diri Dan Ekspresi Budaya Lokal Suju-Suku Bangsa Di Indones., pp. 35-76, 2012.

[3] A. R. Amalia, "Tradisi Perkawinan Merariq Suku Sasak Di Lombok: Studi Kasus Integrasi Agama dengan Budaya Masyarakat Tradisional." Jakarta: Fakultas Ushuluddin dan Filsafat UIN Syarif Hidayatullah, 2017.

[4] A. K. Kholidi, "Tradisi Merarik Masyarakat Bangsawan Dan Masyarakat Biasa Suku Sasak Di Lombok," Skripsi, UIN Sunan Kalijaga Yogyakarta, 2016.

[5] N. Hidayati, "Persepsi tokoh agama terhadap eksistensi perkawinan beda kasta dalam masyarakat bangsawan sasak di Desa Pringgarata Kecamatan Pringgarata Lombok Tengah.” Universitas Islam Negeri Mataram, 2019.

[6] H. Hasanah, "Respon tokoh agama dan tokoh masyarakat terhadap tradisi nikah bangsawan non bangsawan (studi kasus kelurahan Tiwu Galih Kecamatan Praya Kabupaten Lombok Tengah).” Universitas Islam Negeri Mataram, 2018.

[7] B. W. Paramita, "Pandangan bangsawan sasak terhadap perkawinan bangsawan sasak antar suku (studi di Desa Penujak Kecamatan Praya Barat Kabupaten Lombok Tengah).” Universitas Islam Negeri Mataram, 2018.

[8] Koentjaraningrat, Pengantar ilmu antropologi. Aksara Baru, Jakarta, 2005.

[9] L. B. Windia, Manusia Sasak: bagaimana menggaulinya? Genta Press, 2006.

[10] H. Hilman, "Hukum Perkawinan Adat," Bandung: Citra Aditya Bakti, 1995.

[11] M. Harlan, “Tradisi Merarik Suku Sasak," CV Pustaka Bangsa Mataram, 2019.

[12] M. N. Aminullah, "Akulturasi Islam dengan Tradisi Perkawinan Masyarakat Bangsawan Sasak (Studi di Kecamatan Kopang Kabupaten Lombok Tengah)," Palapa, vol. 5, no. 1, pp. 109-137, 2017.

[13] A. Z. Nirmala, "Pelaksanaan Akibat Hukum Perkawinan Menak dengan Jajar Karang pada Masyarakat Suku Sasak (Studi di Desa Rarang, Kecamatan Terara, Lombok Timur)," Kumpul. J. Mhs.
Fak. Huk., 2015.

[14] B. Basriadi, "Tinjauan Hukum Islam terhadap Perkawinan Beda Kelas Muslim Sasak di Lombok," Maraji J. Ilmu Keislam., vol. 1, no. 2, pp. 297-329, 2015 .

[15] H. S. Haq and H. Hamdi, "Perkawinan Adat Merariq Dan Tradisi Selabar Di Masyarakat Suku Sasak," Perspekt. Kaji. Masal. Huk. dan Pembang., vol. 21, no. 3, pp. 157-167, 2016. 